11. Папкова О.А. Усмотрение суда. М.: Статут, 2005. 413 с.

12. Огилец А.А. Процессуальные, тактические и психологические аспекты усмотрения следователя: дисс. ... канд. юрид. наук: 12.00.09. Краснодар, 2005. 190 с.

13. Никонов М.А. Судейское усмотрение: уголовно-процессуальные аспекты: дисс. ... канд. юрид. наук: 12.00.09. Москва, 2013. 272 с.

14. Про затвердження порядку складання досудової доповіді: Наказ Міністерства юстиції України від 27.01.2017 № 200/5. URL: https://zakon.rada.gov.ua/laws/show/z0121-17/print (дата звернення: 09.01.2020).

ШУМЕЙКО Д.О.

\title{
ОКРЕМІ ПРОБЛЕМИ МІЖНАРОДНОГО СПІВРОБІТНИЦТВА ПІД ЧАС ЗДІЙСНЕННЯ СПЕЦІАЛЬНОГО КРИМІНАЛЬНОГО ПРОВАДЖЕННЯ
}

У статті досліджено поняття, форми, нормативну основу міжнародного співробітництва у кримінальному провадженні. Визначено особливості практичної реалізації окремих форм міжнародного співробітництва під час здійснення спеціального кримінального провадження з урахуванням українських, міжнародних нормативних актів та практичної діяльності правоохоронних органів. Зазначено, що зміст Кримінального процесуального кодексу України визначає такі форми міжнародного співробітництва: міжнародну правову допомогу; видачу осіб, які вчинили кримінальне правопорушення (екстрадицію); кримінальне провадження у порядку перейняття; визнання та виконання вироків іноземних держав та передачу засуджених осіб.

Визначено проблемні питання міжнародного співробітництва під час здійснення спеціального кримінального провадження, серед яких тривалість та якість виконання запитів і доручень, ризики, пов'язані із реалізацією заходів міжнародного співробітництва у спеціальному кримінальному провадженні. Запропоновано врахування практичних положень, що нададуть можливість усунути недоліки, пов'язані з підготовкою та визначенням змісту запитів про надання міжнародної правової допомоги. Надано пропозиції щодо вжиття низки специфічних організаційно-тактичних заходів з метою екстрадиції осіб, які ухиляються від особистої участі у провадженні, зокрема: здійснення дій задля екстрадиції до застосування процедури in absentia; аналіз законодавства запитуваної держави у частині допустимості процедури in absentia за внутрішнім правом та/або видачі осіб, до яких вона була застосована та кримінальної відповідальності за таке правопорушення; підтвердження дій запитуючої сторони щодо отримання прав підозрюваного, обвинуваченого, що включають інформацію про належне повідомлення особи про кримінальне провадження, забезпечення права на захист, доступ до суду; визначення i оцінка неофіційних або спеціальних каналів співробітництва, що використовуються зацікавленими державами поза механізмами співпраці, передбаченими відповідними міжнародними договорами, але у відповідності до їх норм і принципів.

Ключові слова: міжнародне співробітниитво, кримінальне провадження, екстрадиція, запит про надання міжнародної правової допомоги, спеиіальне кримінальне провадження.

( ) ШУМЕЙКО Д.О. - кандидат юридичних наук, доцент, старший викладач кафедри кримінального процесу (Національна академія внутрішніх справ) 
The article explores the concepts, forms, normative basis of international cooperation in criminal proceedings. The peculiarities of practical implementation of certain forms of international cooperation during the implementation of special criminal proceedings, taking into account Ukrainian, international regulations and practical activity of law enforcement agencies, are determined. It is stated that the content of the Criminal Procedure Code of Ukraine defines the following forms of international cooperation: international legal assistance; extradition of persons who have committed a criminal offense (extradition); criminal proceedings in the order of transfer; recognition and enforcement of sentences of foreign states and transfer of convicted persons.

Problems of international cooperation in the course of special criminal proceedings are identified, including the duration and quality of the execution of requests and orders, the risks associated with the implementation of measures of international cooperation in special criminal proceedings. Practical provisions are suggested to address the shortcomings involved in the preparation and determination of the content of requests for international legal assistance. Suggestions were made to take a number of specific organizational and tactical measures to extradite persons who evade personal involvement in the proceedings, in particular: to take actions for extradition before applying the procedure in absentia; analysis of the law of the requested State as to the admissibility of the in absentia procedure under domestic law and / or the extradition of persons to whom it was applied and criminal liability for such an offense; confirmation of the action of the requesting party to obtain the rights of the suspect, accused, including information on the proper notification of the person about the criminal proceedings, protection of the right to defense, access to court; identifying and evaluating informal or ad hoc channels of cooperation used by the States concerned outside the cooperation mechanisms provided for in the relevant international treaties but in accordance with their rules and principles.

Key words: international cooperation, criminal proceedings, extradition, request for international legal assistance, special criminal proceedings.

Вступ. Кримінальний процесуальний кодекс України (далі - КПК України) у межах категорії «міжнародне співробітництво під час кримінального провадження» визначає поняття міжнародної правової допомоги, екстрадиції, передачі (прийняття) засуджених осіб, виконання вироків та інших питань.

Зважаючи на актуальність, питання міжнародного співробітництва у кримінальному судочинстві активно вивчаються та досліджуються, отже, напрацьовано змістовний науковий матеріал, звернення до якого дозволить сформувати уявлення про нормативно-правове регулювання міжнародного співробітництва під час здійснення спеціального кримінального провадження (далі - СКП).

Аналіз останніх досліджень та публікацій. Проблеми міжнародного співробітництва у кримінальному провадженні та спеціальному кримінальному провадженні вивчались у працях Ю.П. Аленіна, А.Г. Веніамінова, О.Г. Виноградової, В.М. Волженкіної, Т.С. Гавриш, В.П. Зиміна, I.М. Зубова, В.В. Зуєва, І.В. Лукашука, М.І. Пашковського, В.В. Сердюка, I.I. Сливича, М.І. Смирнова, Ю.Б. Стринатко, О.М. Толочка, А.В. Шевчишена та інших.

Постановка завдання. Метою статті $є$ з'ясування проблем здійснення окремих форм міжнародного співробітництва під час здійснення спеціального кримінального провадження та визначення можливих шляхів їх розв'язання.

Результати дослідження. Міжнародне співробітництво визначають як міждержавну форму співробітництва у протидії злочинності, що здійснюється на підставі міжнародних угод, або на засадах взаємності, між компетентними органами держав у вигляді і запиту на проведення кримінальних процесуальних або інших дій [1, с. 78]. новлять:

Правову основу міжнародного співробітництва під час кримінального провадження ста-

1) міжнародні угоди про співробітництво ратифіковані Україною (Свропейська конвенція про нагляд за умовно засудженими або умовно звільненими правопорушниками від 30 листопада 1964 року і ратифікована Україною 22 вересня 1995 року: Конвенція Ради Свропи про заходи щодо протидії торгівлі людьми від 16 травня 2005 року і ратифікована Україною 16 січня 2008 року); 
2) інші міждержавні багатосторонні договори, ратифіковані Україною, що містять елементи правової допомоги (Конвенція ООН про незастосування строку давності до воєнних злочинів і злочинів проти людства від 26 листопада 1968 року, ратифікована Україною 25 березня 1969 року; Міжнародна конвенція ООН про боротьбу з фінансуванням тероризму від 9 грудня 1999 року і ратифікована Україною 12 вересня 2002 року);

3) двосторонні договори про правову допомогу у кримінальних справах із країнами як ближнього, так і далекого зарубіжжя (Договір між Україною та Канадою про взаємодопомогу у кримінальних справах від 23 вересня 1996 року; Договір між Україною та Сполученими Штатами Америки про взаємну правову допомогу у кримінальних справах від 10 лютого 2000 року);

4) міжвідомчі договори про правову допомогу у кримінальних справах із країнами як ближнього, так і далекого зарубіжжя (Угода між Генеральною прокуратурою України і міністерством юстиції Республіки Польща на виконання статті 3 Договору між Україною і Республікою Польща про правову допомогу та правові відносини у цивільних і кримінальних справах від 24 травня 1993 року);

5) рішення Європейського суду з прав людини (справа «Новік проти України», заява № 48068/06, рішення від 18 грудня 2008 року; справа «Ахмадпур проти Туреччини», заява № 12717/08, рішення від 15 червня 2010 року);

6) нормативно-правові акти, які регулюють порядок і процедуру здійснення міжнародного співробітництва у кримінальному процесі України (КПК України, КК України, закони, накази, інструкції).

За відсутності міжнародного договору України міжнародна правова допомога чи інше співробітництво може бути надано на підставі запиту іншої держави чи запитано на засадах взаємності [2, с. 8].

У Інструкції про порядок здійснення міжнародного співробітництва з питань взаємної правової допомоги, видачі правопорушників (екстрадиції), передачі (прийняття) засуджених осіб, виконання вироків та інших питань міжнародного судового співробітництва у кримінальному провадженні під час судового провадження зазначено, що обсяг правової допомоги, порядок зносин, вимоги щодо форми й змісту запиту (доручення, прохання, клопотання), а також особливості виконання запитів визначаються положеннями міжнародного договору України, який діє у відносинах між Україною та відповідною іноземною державою, та Кримінальним процесуальним кодексом України.

Заяви та застереження, висловлені державами щодо міжнародного договору, є його невіддільною частиною. Під час застосування багатостороннього міжнародного договору України його положення діють з урахуванням заяв і застережень України, висловлених у законі під час ратифікації чи приєднання, та заяв і застережень відповідної іноземної держави.

Посилання на міжнародний договір України в запиті (дорученні, проханні, клопотанні) $є$ обов'язковим, крім випадків, коли запит складається на основі принципу взаємності [3].

Зі змісту КПК України убачається, що законодавець визначає форми міжнародного співробітництва, до яких відносить:

- міжнародну правову допомогу;

- видачу осіб, які вчинили кримінальне правопорушення (екстрадицію);

- кримінальне провадження у порядку перейняття;

- визнання та виконання вироків іноземних держав та передача засуджених осіб.

Особливостей міжнародного співробітництва під час здійснення СКП у КПК України не передбачено, проте науковці справедливо звертають увагу на важливі аспекти, що пов'язані з реалізацією деяких його форм.

I.I. Сливич зазначає, що згідно з Свропейською конвенцією про видачу правопорушників підставами до відмови у видачі $є$ політичний характер вчиненого особою правопорушення, можливість застосування до неї смертної кари. Національні закони також визначають можливості відмови в екстрадиції, законодавство деяких країн (наприклад, Португалії) забороняє екстрадицію у разі можливого призначення не лише смертної кари, а й довічного ув'язнення; екстрадиційні закони Швеції та Ісландії доповнюють підстави відмови віком особи або станом ії̈ здоров'я.

Своєю чергою Конвенція про захист прав людини і основних свобод, Статут Міжнародного кримінального суду (п. $1 \mathrm{~d}$ ст. 67), Міжнародний пакт про громадянські і політичні права (п. 3d ст. 14) передбачають право обвинуваченого на справедливий судовий розгляд та право бути судимим за умов особистої присутності. В цих документах особиста присутність на судовому процесі особи розглядається як фундаментальна гарантія на справедливий розгляд справи, за загального 
негативного ставлення до заочного розгляду кримінальних справ, що пов'язано 3 можливими зловживаннями в процесі заочного провадження.

Саме тому, згідно зі ст. 3 Другого додаткового протоколу від 17 березня 1978 року до Свропейської конвенції про захист прав людини, не можна видавати особу, якщо вона вже засуджена заочно, а в Типовому договорі ООН про екстрадицію передбачено, що видача не дозволяється, якщо судове рішення винесено заочно, а засуджена особа не мала достатньої можливості для забезпечення свого захисту і не мала або не буде мати можливості для проведення повторного слухання справи в їі присутності (ст. $3 \mathrm{~g})$.

У той же час у преамбулі Резолюції 75 (11) Комітету Міністрів Ради Європи наголошується, що, незважаючи на те, що присутність обвинуваченого під час розгляду справи в суді $є$ надзвичайно важливою, можливість спрощення розгляду без слухання справи не повинна бути виключеною. В тексті Резолюції визначено, що справа не може бути розглянута, якщо обвинуваченому не було надано можливостей підготувати свій захист, якщо цій особі не вистачило часу, щоб з'явитися до суду внаслідок того, що вона не була сповіщена про час і місце судового засідання, якщо тільки не буде встановлено, що ця особа навмисно прагнула уникнути правосуддя [4, c. 286-287].

Автор (I.I. Сливич) зазначає, що заочне провадження має сенс застосовувати в умовах, коли немає інших механізмів залучити обвинувачену особу до очного провадження, всі можливості в рамках міжнародної правової допомоги вичерпані [4, с. 288].

A.B. Шевчишен визначає проблеми використання міжнародної правової допомоги у провадженнях in absentia та пропонує способи їх вирішення:

- у запитах про надання міжнародної правової допомоги з метою попередження затягування із виконанням міжнародного доручення доцільно просити запитувану сторону надати таку допомогу у певні чітко визначені строки. Якщо такі строки визначені в кримінальному процесуальному законодавстві запитуваної сторони, то у запиті необхідно орієнтуватися на них, а якщо вони не визначені, то варто орієнтуватися на практику здійснення процесуальних дій слідчими у нашій державі. Для оптимізації міжнародного співробітництва у кримінальному провадженні у майбутньому під час укладення багатосторонніх та двосторонніх договорів про взаємну правову допомогу у кримінальних справах Міністерству закордонних справ України необхідно відстоювати включення нормативних приписів щодо строків виконання звернень про надання міжнародної правової допомоги та можливості і підстави їх зміни тільки за рішенням компетентного органу запитуваної сторони з обов'язковим інформуванням про це запитуючої сторони;

- спеціальне досудове розслідування через можливість невизнання його процедур та результатів у окремих державах може вплинути на прийняття рішення компетентним органом такої запитуваної сторони щодо відмови у наданні міжнародної правової допомоги для збирання доказів шляхом проведення процесуальних дій. Під час досудового розслідування у разі ініціювання прийняття процесуальних рішень щодо спеціального досудового розслідування необхідно, коли відома держава, де перебуває оголошена у міждержавний та/або міжнародний розшук підозрювана особа, брати до уваги їі кримінальне процесуальне законодавство і концентруватися спочатку на вирішенні питання щодо екстрадиції цієї особи без прийняття рішення про спеціальне досудове розслідування щодо неї. Якщо буде відмова в екстрадиції такої особи, тоді обгрунтованим і цілком виправданим буде звернення із клопотанням до слідчого судді щодо спеціального досудового розслідування у кримінальному провадженні. Для мінімізації ризиків відмови у наданні міжнародної правової допомоги під час спеціального досудового розслідування та в подальшому під час судового розгляду пропонуємо у ч. 2 ст. $297-4$ КПК України передбачити як один із критеріїв, які повинні бути враховані слідчим суддею під час ухвалення ним рішення щодо дозволу на здійснення спеціального досудового розслідування, результати застосування заходів міжнародного співробітництва у кримінальному провадженні та викласти цю норму у такій редакції:

«2. Під час вирішення питання про здійснення спеціального досудового розслідування слідчий суддя зобов’язаний врахувати наявність достатніх доказів для підозри особи, щодо якої подано клопотання, у вчиненні кримінального правопорушення, а також чи вичерпані всі можливості заходів міжнародного співробітництва у кримінальному провадженні для встановлення місцезнаходження цієї особи та виконання процесуальних дій, які необхідні для досудового розслідування» [5, с. 206-207].

На нашу думку, щодо останнього, то внесення змін до КПК України у запропонованій редакції навряд вирішить проблему, на якій справедливо наголошено. Конструкція «всі можли- 
вості заходів міжнародного співробітництва у кримінальному провадженні для встановлення місцезнаходження цієї особи та виконання процесуальних дій, які необхідні для досудового розслідування» у даному випадку видаються оціночною категорією, адже вичерпний перелік заходів міжнародного співробітництва для кожного кримінального провадження передбачити неможливо, він може різнитись залежно від обставин провадження. Можливо, це питання доцільніше вирішувати на відомчому рівні у контексті організації і тактики розслідування. Крім того, у правозастосовній практиці, ймовірно, виникне проблема, подібна до існуючої щодо оголошення у міжнародний розшук та підтвердженням його здійснення. Тобто виникне питання, чи достатньо направлення офіційних документів у рамках міжнародного співробітництва, чи потрібно, щоб запитувана сторона надала відповідь або вжила дієвих (яких саме?) заходів на виконання запиту (доручення, прохання, клопотання).

Підтримує позицію щодо необхідності вжиття усіх можливих заходів міжнародної правової допомоги задля екстрадиції як альтернативу СКП В.В. Зуєв і зазначає, що заочне провадження має розглядатися як альтернатива екстрадиції у разі, якщо держава фактично вичерпала можливості залучити особу, яка переховується за кордоном, до участі у кримінальному провадженні. На користь цього підходу свідчить той факт, що у КПК України з'явилися норми, які визначають порядок спеціального провадження, коли провадження відбувається за відсутності підозрюваного або обвинуваченого (in absentia), але при цьому має відповідати загальним засадам кримінального провадження, з урахуванням особливостей, встановлених законом (ч. 2 ст. 7 КПК). Отже, український законодавець сприйняв негативне ставлення до судових процесів in absentia, що пов'язано з розумінням того, що заочні провадження тягнуть за собою можливість порушення права на справедливе судочинство. В принципі, на нашу думку, ці гарантії можна вважати достатніми для того, щоб претендувати на видачу особи, навіть у разі, якщо рішення було ухвалено у спеціальному (заочному) провадженні [6, с.143].

Отже, фахівці цілком слушно визначають проблемні питання міжнародного співробітництва у СКП, серед яких тривалість та якість виконання запитів і доручень, ризики, пов'язані із реалізацією заходів міжнародного співробітництва у СКП.

3 метою удосконалення інституту СКП хотілося б також звернутись до деяких питань екстрадиційної процедури у контексті дотримання прав підозрюваного, обвинуваченого у СКП.

Окремі аспекти, що стосуються прав підозрюваного, обвинуваченого, на яких наголошують міжнародні документи, були згадані раніше. Тут також потрібно звернутись до Конвенції ООН проти транснаціональної організованої злочинності, де у ст. 16 зазначено, що будь-якій особі, у справі якої здійснюється провадження у зв'язку з будь-яким злочином, до якого застосовується ця стаття, гарантується справедливе поводження на всіх стадіях провадження, включаючи здійснення всіх прав і гарантій, передбачених внутрішнім законодавством Держави-учасниці, на території якої знаходиться ця особа.

Ніщо в цій Конвенції не тлумачиться як таке, що встановлює зобов'язання видачі, якщо у запитуваної Держави-учасниці є істотні підстави думати, що прохання про видачу має на меті переслідування або покарання будь-якої особи з причини іiі статі, раси, віросповідання, громадянства, етнічного походження або політичних переконань, або що задоволення цього прохання завдало б шкоди становищу цієї особи через будь-яку із цих причин. [7].

У цитованому документі окремо наголошено на нормах внутрішнього права, яке в Україні передбачає, що зміст та форма кримінального провадження за відсутності підозрюваного або обвинуваченого (in absentia) повинні відповідати загальним засадам кримінального провадження з урахуванням особливостей, встановлених законом. Сторона обвинувачення зобов'язана використати всі передбачені законом можливості для дотримання прав підозрюваного чи обвинуваченого (зокрема, прав на захист, на доступ до правосуддя, таємницю спілкування, невтручання у приватне життя) у разі здійснення кримінального провадження за відсутності підозрюваного або обвинуваченого (in absentia) (ч. 2 ст. 7 КПК України).

У Керівництві ООН з питань взаємної правової допомоги і екстрадиції зазначено, що під час вирішення питання про екстрадицію особи, що була засуджена заочно, і їі екстрадиція запитується для відбуття покарання державам, слід враховувати такі фактори:

- чи було згаданій особі відмовлено в праві на справедливий суд в процесі слухання?

- чи приймала особа, яка розшукується, значну участь у своєму захисті?

- чи буде згаданій особі надано можливість оскаржити вердикт після повернення в запитуючій державі?

- чи може запитуюча держава погодитися на проведення повторного слухання? 
Ось два приклади вирішення питання про те, чи погоджуватися на екстрадицію, або відмовити в проханні про екстрадицію, яка грунтується на вироку, що винесений після закінчення заочного судового розгляду.

Так, розшукуваний злочинець, будучи за професією адвокатом, сховався від правосуддя запитуючої Держави до пред’явлення йому звинувачень, знаючи, що його арешт неминучий. Він був засуджений заочно. Було підтверджено, що в процесі заочного судового розгляду він підтримував контакти з призначеним судом захисником. В цьому разі не було знайдено ніяких юридичних перешкод для його екстрадиції.

В іншій справі був доказ того, що розшукуваний злочинець нічого не знав про пред’явлені йому звинувачення або про суд, який відбувся над ним заочно. Призначений судом захисник розшукуваної особи поступово вичерпав його право оскарження, а внутрішнє законодавство запитуючої держави не допускало проведення нового судового розгляду. В цьому разі в проханні про екстрадицію було відмовлено [8, с. 53].

Ці положення сформульовані із урахуванням норм міжнародного законодавства, що стосуються процедури in absentia та практики ЄСПЛ. Національна правозастосовна практика також орієнтована на них.

Висновки. Задля усунення недоліків, пов’язаних з підготовкою та визначенням змісту запитів про надання міжнародної правової допомоги, у практичній діяльності пропонується враховувати такі положення: 1) відповідність форми та змісту запиту вимогам міжнародного договору, КПК України; вказівка, що запит здійснюється за принципом взаємності (у разі відсутності міжнародного договору); 2) засвідчення запиту (доручення) за відсутності міжнародного договору; 3) відповідність змісту запиту можливому обсягу міжнародної правової допомоги відповідно до міжнародного договору та процесуального законодавства запитуваної держави; 4) зазначення обставин (за наявності), які вказують на пріоритетність розгляду запиту (характер правопорушення, ризик втрати доказів, переховування) і підтвердження того, що запит не спрямований на переслідування за політичними або іншими мотивами, що суперечать засадам кримінального судочинства; 5) зазначення бажаної дати отримання відповіді із посиланням на міжнародний договір (за наявності) або без такого.

Для екстрадиції осіб, які ухиляються від особистої участі у провадженні, має значення вжиття низки специфічних організаційно-тактичних заходів: 1) здійснення усіх можливих дій задля екстрадиції до застосування процедури in absentia; 2) аналіз законодавства запитуваної держави у частині допустимості процедури in absentia за внутрішнім правом та/або видачі осіб, до яких вона була застосована та кримінальної відповідальності за таке правопорушення; 3) підтвердження дій запитуючої сторони щодо отримання прав підозрюваного, обвинуваченого, що включають інформацію про належне повідомлення особи про кримінальне провадження, забезпечення права на захист, доступ до суду. Зі змісту цих заходів має убачатись, як саме вони впливають на обсяг прав підозрюваного, обвинуваченого, і що сприятиме формуванню об'єктивної позиції щодо можливості екстрадиції; 4) визначення і оцінка неофіційних або спеціальних каналів співробітництва, що використовуються зацікавленими державами поза механізмами співпраці, передбаченими відповідними міжнародними договорами але відповідно до їх норм і принципів.

Ці вимоги є актуальними і для випадку запиту про екстрадицію, якщо здійснюється СКП. У такому разі потребує ретельного вивчення законодавство запитуваної держави, зокрема, у частині допустимості процедури in absentia за внутрішнім правом та/або видачі осіб, до яких вона була застосована, у окремих випадках може бути доцільним звернення до компетентних органів цієї держави із повідомленням про намір екстрадиційного запиту у провадженні in absentia i висловлення прохання зазначити про вимоги та умови, яких має дотриматись запитуюча сторона. Це дозволить зробити об'єктивний висновок про характер, обсяг процедурних можливостей і процесуальних обов'язків щодо співробітництва у конкретній справі за наявних обставин.

\section{Список використаних джерел:}

1. Маланчук П.М., Льон О.М., Тарасенко Д.І. Міжнародне співробітництво у кримінальному провадженні. Правові горизонти. 2017. Вип. 3(16). С. 77-81.

2. Удалова Л.Д., Письменний Д.П., Омельченко О.Є. та ін. Міжнародна правова допомога у кримінальному проваджені: навч. посіб. Київ, 2015. 211 с.

3. Про затвердження Інструкції про порядок здійснення міжнародного співробітництва 3 питань взаємної правової допомоги, видачі правопорушників (екстрадиції), передачі (прийняття) засуджених осіб, виконання вироків та інших питань міжнародного судового співробітництва 
у кримінальному провадженні під час судового провадження: наказ Міністерства юстиції від 19 серпня 2019 року. № 2599/5. URL: https://zakon.rada.gov.ua/laws/show/z0956-19 (дата звернення: 01.09.2019).

4. Сливич I.I. Заочне провадження як відповідь на сучасні проблеми у сфері міжнародної правової допомоги у кримінальних справах. Держава і право. Вип. 61. С. 285-289.

5. Шевчишен А. Використання міжнародної правової допомоги для збирання доказів під час спеціального досудового розслідування. Visegrad Journal on Human Rights. 2017. № 2/1. C. 203-208.

6. Зуєв В.В. Кримінальні процесуальні гарантії прав особи при міжнародному співробітництві під час кримінального провадження : монографія. Харків : ТОВ «Оберіг», 2017. 204 с.142.

7. Конвенція Організації Об’єднаних Націй проти транснаціональної організованої злочинності. Прийнята резолюцією 55/25 Генеральної Асамблеї від 15 листопада 2000 року. URL: https://zakon.rada.gov.ua/laws/show/995_789 (дата звернення: 01.09.2019).

8. Руководство по вопросам взаимной правовой помощи и экстрадиции. Управление Организации Объединенных Наций по наркотикам и преступности. Организация Объединенных Наций. Нью-Йорк. 2012. 117 с. 